\title{
Residential Work
}

Roger Clough

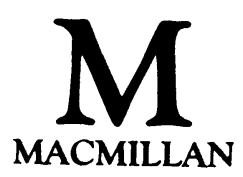


All rights reserved. No reproduction, copy or transmission of this publication may be made without written permission.

No paragraph of this publication may be reproduced, copied or transmitted save with written permission or in accordance with the provisions of the Copyright Act 1956 (as amended).

Any person who does any unauthorised act in relation to this publication may be liable to criminal prosecution and civil claims for damages.

First published 1982

Reprinted 1986

Published by

MACMILLAN EDUCATION LTD

Houndmills, Basingstoke, Hampshire RG21 2XS

and London

Companies and representatives

throughout the world

ISBN 978-0-333-30892-9

ISBN 978-1-349-16931-3 (eBook)

DOI 10.1007/978-1-349-16931-3 


\section{PRACTICAL SOCIAL WORK \\ Series Editor: Jo Campling BASW}

\section{EDITORIAL ADVISORY BOARD}

Terry Bamford, Malcolm Payne, Peter Riches,

Patrick Phelan, Jane Tunstill, Sue Walrond-Skinner

\section{PUBLISHED}

Social Work and Mental Handicap

David Anderson

Social Workers at Risk

Robert Brown, Stanley Bute and Peter Ford

Social Work and Mental Illness

Alan Butler and Colin Pritchard

Residential Work

Roger Clough

Welfare Rights Work in the Social Services Geoff Fimister

Computers in Social Work

Bryan Glastonbury

Working with Families

Gill Gorell Barnes

Social Work with Old People

Mary Marshall

Applied Psychology for Social Workers

Paula Nicolson and Rowan Bayne

Crisis Intervention in Social Services

Kieran O'Hagan

Social Work with Disabled People

Michael Oliver

Social Care in the Community

Malcolm Payne

Working in Teams

Malcolm Payne

Adoption and Fostering

Carole R Smith

Social Work with the Dying and Bereaved Carole R. Smith

Community Work

Alan Twelvetrees

Working with Offenders

Hilary Walker and Bill Beaumont (eds)

\section{FORTHCOMING}

Social Work and Child Abuse David Ball and David Cooper

Childhood and Adolescence

Alan Butler and Michael Kerfoot

Sociology in Social Work Practice

Peter Day

Student Supervision in Social Work

Kathy Ford and Alan Jones

Child Sexual Abuse

Danya Glaser and Stephen Frosh

Women and Social Work

Jalna Hanmer and Daphne Statham

Social Work with Ethnic Minorities

Alun C Jackson and Lena Dominelli

Youth Work

Tony Jeffs and Mark Some

Divorce and Separation

Lisa Parkinson

Group Work

Michael Preston-Short

Court Work

Carole Smith, Mary Lane and Terry Walshe

Child Care

Jane Tunstill 


\section{PRACTICAL SOCIAL WORK \\ Series Editor: Jo Campling BASW}

Editorial Advisory Board:

Terry Bamford, Malcolm Payne, Peter Riches,

Patrick Phelan, Jane Tunstill and Sue Walrond-Skinner

Social work is at an important stage in its development. All professions must be responsive to changing social and economic conditions if they are to meet the needs of those they serve. This series focuses on sound practice and the specific contribution which social workers can make to the wellbeing of our society in the 1980 s.

The British Association of Social Workers has always been conscious of its role in setting guidelines for practice and in seeking to raise professional standards. The conception of the Practical Social Work series arose from a survey of the BASW members to discover where they, the practitioners in social work, felt there was the most need for new literature. The response was overwhelming and enthusiastic, and the result is a carefully planned, coherent series of books. The emphasis is firmly on practice, set in a theoretical framework. The books will inform, stimulate and promote discussion, thus adding to the further development of skills and high professional standards. All the authors are practitioners and teachers of social work, representing a wide variety of experience.

Jo CAmpling 


\section{Contents}

Acknowledgements

ix

1 Residential Homes in Society 1

Residential living 1

Who are the residents? 3

The need for residential homes 5

Residential homes and other styles of residential

living 9

Schools for juvenile delinquents $\quad 11$

Children's homes $\quad 12$

Old age homes 15

Residential centres and the community $\quad 17$

Attitudes to residential homes 18

The justification of residential work $\quad 20$

Systems of management $\quad 21$

Costs and resources $\quad 24$

2 Styles and Beliefs 28

Introduction 28

Distinctive features of the resident group $\quad 30$

Stated function of the residential home 31

Location $\quad 34$

Style $\quad 35$

System of management $\quad 38$

Ideologies and beliefs $\quad 39$

Sources of belief $\quad 40$

Implications for practice $\quad 45$ 
vi Contents

3 Meeting Material and Physical Needs 47

Meal-times $\quad 50$

Getting up and going to bed $\quad 55$

Clothing $\quad 58$

Dependence and choice $\quad 59$

Principles in planning $\quad 59$

4 Thinking about Practice 62

Assessment 64

Analysis and theorising $\quad 66$

Time for reflection $\quad 67$

Planning 68

Planning the task of the centre $\quad 70$

Who needs to plan? $\quad 71$

Written agreements $\quad 73$

Individual assessments and reviews $\quad 76$

Setting and achieving objectives $\quad 76$

Who does what? $\quad 78$

5 Working in a Team $\quad 81$

Distinctive characteristics of residential work $\quad 81$

Residential units and accountability $\quad 82$

Types of team $\quad 83$

Objectives of the staff team $\quad 84$

$\begin{array}{ll}\text { Methods } & 87\end{array}$

Sharing with colleagues $\quad 89$

Support for staff $\quad 89$

Working co-operatively $\quad 91$

6 Rights 95

The need for rights for residents 95

What sort of rights? 99

Transfer of power 101

Defining rights 101

Rights on admission $\quad 102$

Daily living rights 103

Rights of others 105

$\begin{array}{ll}\text { Protection of rights } & 107\end{array}$ 
7 Evaluation $\quad 110$

$\begin{array}{ll}\text { Framework } & 110\end{array}$

Criteria of success $\quad 113$

Methods of evaluation $\quad 117$

8 In Perspective 122

Stability, security and continuity 123

Power for the weak $\quad 125$

Stressing normality $\quad 125$

Living with others $\quad 127$

What is residential work? 131

Changing boundaries $\quad 134$

In conclusion $\quad 135$

Further Reading 136

References 138

$\begin{array}{ll}\text { Index } & 142\end{array}$ 


\section{Acknowledgements}

I am aware of three main influences on this book: first, from my time as a residential worker; second, from students and staff at Bristol University; and third, from my family.

Young, fresh from college, I worked as a teacher and housemaster at Banstead Hall and Park House, two senior boys' approved schools. Not everything was good (one routine I remember was to line up the boys to be checked off while I squeezed toothpaste on to their brushes!) but there were some good times too. Most importantly I came to realise the need to create a culture or style of living that would be agreed by staff and boys.

At the university I have shared in the stimulation of working with staff and students on the post-qualifying course in residential social work. We try to look at theory and at action, indeed at theory for action - and it has been a privilege to work with practitioners who invest and share so much.

Residential work is concerned with arrangements for living. As I have thought about the ideas developed in this book, I have related them to my present 'residential life', my life with my family. Often unbeknown to them I have looked at the way we manage meals or bed-times, and smiled wryly at my own attempts to plan. If the children ever read this, they will know a part of how I thought it ought to be.

In addition to my general thanks to these three groups of people, I am grateful to Christopher Beedell, Phyllida Parsloe and David Watson for detailed comments on the text. Avon Social Services Department authorised my use of their figures and Andrew Edgington prepared the information for me. 